\title{
Religious Education in Public Schools in Western Europe
}

\author{
Mercedes Llorent-Vaquero ${ }^{1}$ \\ ${ }^{1}$ Faculty of Education Sciences, University of Seville, Seville, Spain \\ Correspondence: Mercedes Llorent-Vaquero, Dpto. de Didáctica y Organización Educativa. Fac. de CC. de la \\ Educación, Calle Pirotecnia s/n, 41013 Sevilla, Spain. Tel: 349-5542-0601. E-mail: mllorent@us.es
}

Received: August 30, 2017

Accepted: September 30, 2017

Online Published: December 29, 2017

doi:10.5539/ies.v11n1p155

URL: https://doi.org/10.5539/ies.v11n1p155

\begin{abstract}
Christianity is one of the cultural and ethical cornerstones of Europe. In the European Union (EU) there is no overarching policy on religious education (RE) in the school system. The authors use a comparative methodology to analyze the constitutions of Western European countries in relation to different aspects of RE. Specifically, it is focused in Germany, Austria, Belgium, France, Ireland, Luxembourg and the Netherlands. Whereas the right to religious freedom for all is clearly established in these constitutions, obvious differences are revealed in the legal provisions for and attitudes towards religious education. For example, the legal framework of this education has been included in the constitutions of all the analyzed countries, except in the case of France. Also, optional subjects are on offer in Germany, Belgium, the Netherlands, and Luxembourg, however no alternative subjects to RE are on offer in Austria. In this sense, the authors defend that it is essential to open up the academic dialogue about religious and spiritual issues.
\end{abstract}

Keywords: religion, education, Europe, school, constitution

\section{Introduction}

The policies planned at the heart of the European Union (EU) and favoring the establishment of a joint identity are encouraging initiatives for the creation of a European Constitution and more homogenized national education systems. In turn, the role of religious education within these systems is questioned in order to predict and shape their future.

In order to fully comprehend the current European culture it is necessary to take into account the pillars which have gradually formed it over time, including religion. Europe, far from being a monolithic block, is made up of a diverse set of communities whose histories are steeped in religious experiences and beliefs.

Without expounding on the unavoidably complex history of the current situation, it should be highlighted that if we are to fully examine and understand this phenomenon we need a suitable historical cultural perspective which goes beyond our competence. However, it should be noted that for centuries Christianity permeated and radically influenced European society, in art, language, laws, morality, music, politics, family life... even in our way of thinking. In this regard, the history of Europe cannot be understood without taking into account the advent of Christianity, its subsequent expansion, or the religious conflicts of the 15th and 17th centuries.

Religious education in schools has been greatly affected by the changing relationships between Church and State (Hand, 2015). In the 19th century, the balance established between State and society brought about a concept of secular State where religion was limited to the private sphere. However, as both fields were clearly outlined in the 20th century the state took on a subsidiary role in society, where freedom covered the religious aspects of teaching (Goodman, 2016). The religious neutrality of the State was respected, and parents could choose the religious education of their children. In fact, after the Second World War in Western Europe protection was guaranteed for human rights, the secular nature of education was blurred, and the tendency was to grant parents the right to educate their children freely according to their personal religious beliefs. This meant that religion moved beyond the private spheres and into state schools, although not in France, where compulsory state education continues to be totally secular.

\subsection{International Declarations and Recommendations}

The Universal Declaration of Human Rights (United Nations General Assembly, 1948) guarantees the rights of everyone in its article 18 "to freedom of thought, conscience and religion; this right includes freedom to change 
his religion or belief, and freedom, either alone or in community with others and in public or private, to manifest his religion or belief in teaching, practice, worship and observance".

In addition, it also states in its article 26.2 that: "Education shall be directed to the full development of the human personality and to the strengthening of respect for human rights and fundamental freedoms. It shall promote understanding, tolerance and friendship among all nations, racial or religious groups, and shall further the activities of the United Nations for the maintenance of peace".

However, the interpretations of the texts of international agreements signed by Spain and those of our constitutional charter do not align. Far from constituting a point of union between the different countries and their citizens, the interpretation of this article is a matter of conflict, used to strengthen the arguments for or against religious education in classrooms. The dilemma lies in knowing whether the full development of human personalities requires instruction in religion or not. We thus encounter a part of society chiefly supported by religious communities which consider man to be a religious being by nature, and in turn demand that religion be compulsory within the formal curriculum. In contrast, other sectors of society are opposed to religious education in schools as an integral part of life.

When referring to freedom of thought, conscience and religion, the European Convention on Human Rights of 4 November 1950 (Council of Europe, 1950) states in its article 9.1 that: "Everyone has the right to freedom of thought, conscience and religion; this right includes freedom to change his religion or belief and freedom, either alone or in community with others and in public or private, to manifest his religion or belief, in worship, teaching, practice and observance".

In order to guarantee the rights stipulated in the Convention the additional Protocol is adopted for the protection of Human Rights and Fundamental Freedoms (Council of Europe 20 March 1952), where on the subject of teaching it states in its article 2: "No person shall be denied the right to education. In the exercise of any functions which it assumes in relation to education and to teaching, the State shall respect the right of parents to ensure such education and teaching in conformity with their own religious and philosophical convictions".

The Universal Declaration of Human Rights took on the form of an international legal norm when two major agreements were signed, in the articles 18.4 and 13.3 (UNESCO, 1966):

1) In the International Covenant on Civil and Political Rights, the Party States undertake to "have respect for the liberty of parents and, when applicable, legal guardians to ensure the religious and moral education of their children in conformity with their own convictions".

2) With the International Covenant on Economic, Social and Cultural Rights, the Party States also undertake to respect the freedom of parents, and when applicable legal guardians, to choose for their children or wards to attend schools other than those set up by public authorities, providing they meet the minimum requirements set or approved by the State as regards education, and ensuring their children or wards receive religious or moral education in line with their convictions.

The Covenant on the fight against discrimination in education (UNESCO, 1960) stated in its article 5.1 that the freedom of parents to provide their children with the religious training they consider suitable, in agreement with their own beliefs and conviction, must be respected.

In the Declaration on the Elimination of All Forms of Intolerance and of Discrimination Based on Religion or Belief (General Assembly UN, 1981) it is stated that parents may educate their children in morals and religion in line with their own beliefs within the family context. Children have the right to receive a religious education according to the preferences of their parents, with the greater interest of children as a guiding principle. In the event of the minor not being in the charge of parents or guardians, the child's interests are taken into account.

In the Convention on the Rights of the Child, adopted by the General Assembly of the UN (General Assembly UN, 1989) it is stated, in its article 27.1, that Party States must recognize the rights of all children to a standard of living suited to their physical, mental, spiritual, moral and social development.

The Charter of Fundamental Rights of the European Union (European Union, 2000) categorically states that, according to national legislation, it is necessary to respect the freedom to set up educational institutions respecting democratic principles, as well as the right of parents to guarantee the education and instruction of their children according to religious, philosophical and pedagogic convictions.

The Consultative Assembly of the Council of Europe, dedicated to Religion and Democracy (Parliamentary Assembly, 1999), advised the Ministers' Committee to invite the governments of the Member States to promote and develop religious education, establishing as specific suggestions: 
- That religious education becomes a means for promoting a set of values that allow younger generations space for reflection and understanding within a democratic and ethical education.

- $\quad$ To encourage education in all world religions, analyzing them comparatively and eventually identifying their main ideals.

- To encourage the study of religions, not only in compulsory education and among children, but as part of actions and research at university level.

- $\quad$ To attempt to prevent any quandaries caused by the beliefs of children's parents and the religious education established by the state in order to ensure respect of the freedom to decide of families.

\subsection{Constitutions and Religion}

Controversies and discrepancies arose when attempts were made to define the major role played in the past and at present by Christianity in the EU (Barnes \& Felderhof, 2014). When drafting the Constitutional Treaty of the EU, the mere inclusion in its Preamble of an expression mentioning the "Christian roots" of European societies divided the countries. Twelve countries defended its inclusion: Germany, Austria, Slovakia, Spain, Hungary, Ireland, Italy, Lithuania, Malta, Netherlands, Poland and Portugal, all countries which were Catholic or mostly Catholic. Its inclusion was finally ruled out due to rejection from Belgium, Cyprus, Denmark, Slovenia, Estonia, Finland, France, Greece and Latvia, who claimed this could jeopardize a possible European secular identity (Petschen, 2008). Despite the fact that this statement was simply the expression of an undeniable historical fact, it was considered politically inconvenient.

The European Constitution (European Union, 2005) includes, in its article II-74, the right to free and compulsory education, the liberty to set up educational centers, and to guarantee to parents that their children will be educated and taught in line with their religious beliefs. Freedom of education is thus associated with religious freedom.

Nevertheless, differences - to be examined at a later stage - become apparent when comparing the German version of the European Constitution which does refer to the religious values of the EU, to the official version in which the French stance speaks only of spiritual values.

The rejection of the Constitutional Treaty by some countries brought about a constitutional crisis in the EU which finally ended with the ratification and implementation of the Lisbon Treaty, modifying the European Union Treaty and the Constitutive Treaty of the European Community. The aspect of religion was modified with the inclusion in the Preamble of the following text:

Drawing inspiration from the cultural, religious and humanist inheritance of Europe, from which have developed the universal values of the inviolable and inalienable rights of the human person, freedom, democracy, equality and the rule of law (EUR-Lex, 2004).

The difficulties of a common policy on this are highlighted after observing differences in the treatment given to religion in the constitutions of each member country. The table below shows the legal basis established in each country mostly based on the right to religious freedom and when applicable to religious education taught at primary and secondary school level.

\section{Method}

Given the ongoing difficulties that EU countries are experiencing in adopting a common stance on religion, this study focuses on examining the current differences and similarities of the situation of Germany, Austria, Belgium, France, Ireland, Luxembourg and the Netherlands. To do so, we aim to analyze the constitutional and legal framework to ascertain how far the rights and obligations of parents in educating their children extend, as well as the freedom to choose religious education (RE) in state schools, and the safeguarding of the approvals of RE curricula and textbooks. For this purpose a characteristic methodology in Comparative Education is used, following the phases proposed by García (1996) and Llorent-Bedmar (2002). The comparison units are the selected countries between of which similarities and differences have been highlighted. This study was based on the original version of the National Constitutions of each country.

\section{Results}

The difficulties of a common policy are highlighted after observing differences in the treatment given to religion in the constitutions of each member country. The table below shows the legal basis established in each country mostly based on the right to religious freedom and when applicable to religious education taught at primary and secondary school level. 
Table 1. Constitutions, education and religion

\begin{tabular}{ll}
\hline Country & State and Education \\
\hline & Freedom of education remaining loyal to the Constitution $(\operatorname{art.~5,3).}$ \\
Germany & Educational system under the supervision of the State (art. 7, 1).
\end{tabular}

Austria

The Federation is in charge of the legislation and execution of schooling (art. 14.1).

Guarantees the enjoyment of rights and freedoms (art. 11),

Belgium categorically determining the freedom of education and the prohibition of any measures preventing or hindering it (art. 24).

France

The law determines the main principles of education (art. 34).

State and Religion

Those in charge of the child's education have the right to decide on religious education. This type of teaching takes the form of an ordinary subject in state schools, except in secular schools (art. 7, 2-3). Religious education in schools attended to by the Church or religious community in charge. The state is responsible for the management and supervision of education (Annex 1: art. 17).

All minors must be open to political, religious and ideological thought in order to take part in the cultural and economic life of Austria, Europe and the World, as well as in common missions of peace and love of peace (art. 14. 5a)

Education described as neutral, implying respect for philosophical, ideological or religious beliefs of parents and students (art. 24.5).

Students of compulsory school age with a right to moral and religious education (art. 24.3). State schools offer in obligatory schooling the chance to choose between the teaching of a specific recognised religion or a secular moral education (art. 24.1).

France is a non-divisible, secular, democratic, and social Republic which guarantees equality in the eyes of the law for all citizens, regardless of origin, race or religion and respecting all beliefs (Preamble, art. 1).

The State recognises that public worship is due to Almighty God. The State shall reverence his name, respecting and honouring religion (art. 44.1).

The State must ensure children of schooling age receive basic education, respecting the educational wishes of parents. The family is recognised as primary and natural educating agent, respecting the right and obligation of parents to take charge of the religious, moral, intellectual, physical and social education of their children (art. 42.1).

The State provides free primary education and makes an effort to complement private initiatives (art. 42.2).

Luxembourg

The State must ensure that all Luxembourgers receive primary education, which will be obligatory and free (art. 23).

Education is the object of constant attention from the Government. (art. 23.1). It is executed freely, yet may be supervised, and teachers will have to pass an ability and morality exam (art. 23.2). All

municipalities provide basic public education (art. 23.4).

Netherlands

Source. Die Verfassung des Deutschen Reichs, 1919; Die Österreichische Bundesverfassung, 1920; Constitution de la Belgique, 1994; Constitution de la République française 1958 ; Constitution of Ireland, 2004; Constitution du Grand-Duché de Luxembourg, 1868; Verfassung des Königreiches der Niederlande, 1983.

\subsection{Germany}

This type of education is characterized by the agreements signed between the religious confessions and each of the sixteen länder (states). RE is provided in state and private schools and is included in the curricula for primary and secondary education. It is presented as an optional ordinary subject (Religionsunterricht), but with academic 
effects. Although it depends on individual states, there are normally two hours of class a week. Parents are chiefly in charge of choosing the subjects to be taught to their children in accordance with faith and religious belief. From the age of 14, students can freely decide whether or not they want to study RE, as well as the educational itinerary or doctrine they desire for their education. The predominant religious confession, Catholic or Protestant, varies depending on the state. Content taught is ultimately the responsibility of religious communities, as is the selection of textbooks and teacher training. RE is a regular subject in state schools with the exception of secular schools. Without detriment to the right to state supervision, RE is taught in keeping with the main principles of religious communities).

According to the Bremen Clause (Parlamentarischen Rat, 1949), RE is voluntary and the responsibility of the Church, except in the states of Bremen, Berlin and Brandenburg, with legislation predating the Basic Law (Rodríguez, 2004). The German education system offers alternative subjects to RE. Their naming and content depend on individual states. These optional subjects are Philosophy, Ethics, Values and Norms and Free Study (Spanish Centre for Educational Research and Documentation, 2001).

\subsection{Austria}

Despite the institutional and organizational separation in Austria between Church and State there is reciprocal cooperation between both bodies as regards religious education: "It will be the task of the Austrian school to promote the development of talents and the potential skills of students in keeping with ethical, religious and social values" (Austria National Council, 1949).

RE (Religionsunterricht) is regulated by the Religious Education Law of 1949 (Austria National Council, 1949). It is obligatory in state schools until the age of 14, after which it is classed as an optional subject. Legally, all religious communities, Catholic, Protestant and Muslim, are treated equally. It is up to the individual communities to train teachers in the subject, as well as to supervise content and textbooks.

The autonomy of schools allows an independent administration of resources, which according to the Church limits religious education, as it depends on the "religious climate" of individual schools.

Due to the number of students who do not request religious education, some schools have incorporated the alternative subject of Ethics. However, this subject is not yet widely available due to high costs.

\subsection{Belgium}

After endless religious conflicts the School Pact was signed in Belgium in 1959. It guarantees the teaching of religion and moral although there is no official State religion.

At present RE (Godsdienstonderwijs) is compulsory and counts towards the average mark (Serbeto, 2013). Students are allowed to receive an education in one of the religions recognized by the State (Catholic, Protestant, Orthodox, Jewish and Muslim) or receive secular moral education. This is decided by the parents, but there are also special instances, such as in the case of Jehovah's Witnesses, in which the student can be completely exempt from receiving religious education.

At present, discussion is focused on the elimination of both subjects and the inclusion of a single subject combining the history of the different religions, although no changes have been implemented to date.

With the Decree of 1 December 1993 the government established regulations for the inspection and educational support of the subjects of Philosophy and Religion. This means that the inspection service has no competences on RE and every centre which teaches religious subjects has an ad hoc association in charge of study plans, inspection, and support in the courses of Moral Education and Religion. These associations are also in charge of implementing training and retraining courses for the teachers in charge of these subjects. The selection of teachers, curriculum content, and education manuals is the competence of the religious communities themselves, although individual schools have decision-making autonomy.

\subsection{France}

Considering that in $2010,64 \%$ of French citizens declared themselves to be Catholic, while $28 \%$ claimed not to profess any religion (Département Opinion et Stratégies d'Entreprise, 2010), it might be deduced that the country is predominantly Catholic. However, there has long been a strict separation between Church and State which the French are very proud of. Currently, state schools are secular, and religion is excluded from their classrooms. Furthermore, in 2004, following intense debate Law 2004-228 (Assemblée nationale, 2004), applying the principle of secularism to regulate the wearing of signs or clothing manifesting a religious affiliation in state schools, lower secondary and secondary schools was passed, prohibiting the public display of religious symbols in state schools. 
Since the 2013-14 academic year all schools have been obliged to feature the Secularism Charter (Ministère de l'Éducation Nationale, 2013) in a visible location. This charter is a brief text, composed of 15 articles, the first five of which relate to the secularism of the Republic, while the remaining 10 reference secularism in schools. Most of the articles highlight the merits of secularism in school and maintaining it. The Charter explicitly states that France is secular and establishes a clear separation between religions and the State, which is held to be neutral as regards religious or spiritual convictions. It also prohibits all forms of proselytism in schools, ensuring staff are completely neutral in exercising their functions, without expressing their own political or religious beliefs, while transmitting the significance and value of secularism to their students.

No student can claim political or religious conviction when appealing to a teacher in relation to the right to study a part of the programme, and it is forbidden to appeal to religious beliefs when rejecting the rules applicable in schools in the Republic.

Nevertheless, the school calendar specified in the study programme sets aside a half-day a week in primary education so that the different religions can teach RE outside school. In secondary education an hour is left free every week within the school itself so that a chaplain may teach anyone wishing to study RE.

Exceptionally, RE is part of the school curriculum in the regions of Alsace and Lorraine, which conserved their traditional agreement with the Vatican. Attempts are currently being made to gradually negotiate the application of secularism in both regions (UFAL, 2016).

\subsection{Ireland}

The 1937 Constitution reflects the Roman Catholic, social, and educational thinking of the Irish people, as it defends the right of parents to $\mathrm{RE}$ and the role of the state as guarantor of this right. Although there is no religion officially recognized by the State, most citizens are Roman Catholics (European Commission, 2013).

The vast majority of Irish primary schools are under the control of religious communities. Private education is recognized but confessional schools are not necessarily part of this sector.

In primary education, $90 \%$ of schools are both national (or state) and confessional (Christian), as they both profess Christian educational ideas (usually Catholic) and are under the supervision of local committees where the Church - almost always at parish level - has predominant representation. These schools are of course fully funded by the State, resulting in a major degree of State control, albeit with considerable leeway for autonomy, even as regards hiring teaching staff. In no case are they "excludingly confessional", that is to say, they cannot reject students on religious grounds (García, 2006).

In pre-primary (ages 4 to 6 and non-compulsory) and primary education (ages 6 to 12 and compulsory) there are 30 minutes daily for RE (Religious instruction). This is also taught as a compulsory subject in secondary education (obligatory from 12 to 16 ).

Although confessional RE is included in the compulsory curriculum, individually students can opt out of this education (Moreno, 2013), without there being an alternative subject. The 1998 Education Law recognizes the right of parents or tutors to select the education centre depending on their religious choice. From the 1970s parents have taken on a rather active role in the setting up of multi-confessional schools, not very successfully.

The curriculum and study plans for subjects are organized and planned at national level. However, this is not the case with RE due to the rights of the different religions to design and supervise their own curriculum and textbooks.

\subsection{Luxembourg}

In Luxembourg there is no strict separation between State and religion. The Constitution accepts that religious communities carry out an important public role. Therefore, the cooperation between the State and the religious communities is institutionalized through signed agreements. At present, the Catholic, Jewish, Protestant and Anglican communities benefit from different agreements and are funded, with RE teachers also being paid by the State.

Although most Luxembourgers are Catholic - $68.7 \%$ of the population in 2008 - it should be noted that $24.9 \%$ do not profess any religion and there has been a noticeable increase in the Muslim community (Borsenberger \& Dickes, 2011).

As regards the freedom of religious conscience of the children, with the exception of the subject L'instruction religieuse et morale, the 2009 schooling law (Éducation nationale, 2009) establishes that school education cannot privilege any religious doctrine. 
The law on the organization of Primary Education (Éducation nationale 2009) stipulates that the subject of religious and moral education should become a field of learning for second, third, and fourth years. It is obligatory and can be assessed, and is offered as an alternative to the subject of Moral and Social Education. RE is taught 2 hours a week in keeping with the agreement signed between the government and the archdioceses of Luxembourg. The alternative subject is taught in the same time slot. The choice between the religious option or the alternative is made by parents. The RE study programme and the textbooks are set by the Ministry following suggestion of the heads of religious authorities.

\subsection{The Netherlands}

Freedom of religion is guaranteed in the Netherlands, where there is a separation between Church and State. Its society is becoming increasingly secular and the demand for RE is decreasing.

As in most countries, it is possible to find schools governed by public authorities as well as private ones, which are mostly religious. Both types of schools are recognized and approved by the Ministry of Education and state-funded.

Primary education includes the subject "Religious and Ideological Movements", about the religions of the world and their different visions. This subject, introduced in 1985 to encourage tolerance in Dutch society, is offered as an optional subject in schools, and it is up to parents to request it for their children (Pol, 2008).

The goals of RE are structured into three nuclei: A. Personal, contributing to the development of the religious identity of students. B. Social, promoting respect for other religious views of the world and treating morals in society. C. Professional, educating the students in the religious/ideological $/$ moral aspects that can later be developed professionally.

Although RE is part of the Dutch education system, differences can be found depending on the type of educational establishment. For instance, in state schools it is secular and its aim is to educate on the different beliefs. At the same time, private schools are authorized to teach their religion and beliefs as a compulsory part of the curriculum. In this last case study programmes and textbooks are chosen by the individual religious confessions and subsequently approved by the education authorities.

\section{Discussion}

The European Union is a community of states with a good present and an even better future. The continuous negotiation process between the members of this union of States is yielding results that far exceed the merely economic and mercantile. Without a doubt, in recent decades the different peoples that form the EU have been brought closer together, overcoming linguistic and cultural borders, promoting qualification equivalences, greater professional mobility, and a long list of socio-economic advances of great importance. However, the results desired should not create unfounded expectations and lead us to suppose that an educational unification similar to the economic-commercial one is to occur in the short or medium term.

Christianity plays an important role in European societies, defining and guiding models and ways of life for most of its citizens. Considered a basic pillar of their cultural baggage and a vital tool for the transmission of values, it has constituted an essential element in the formation of European states and their national education systems, and can be found in the cultural and ethical foundations of Europe. Therefore, RE is not at all a trivial matter, as all the countries studied integrate it in school curricula.

The legal framework of this education has been included in the constitutions of Germany, Austria, Belgium, Ireland, Luxembourg, the Netherlands, Spain, Greece, Italy and Portugal. In addition, all these constitutions explicitly state the right to freedom of religion (in Belgium, this is implicit). The sole exception is the case of France, where the principle of secularity is held. Only Germany, Austria, Belgium, and Ireland refer to religious education in the school system.

In all the countries studied, except France, this education is included in schools. In France it does not appear on the school curriculum, although it is obligatory in the region of Alsace and the department of Mosela, due to the still applicable Napoleonic concordat with the Holy See (Guénois, 2012).

Luxembourg is an exception to the general separation between Church and State, as it has no strict separation between Church and State or significant connotations: in Germany and Austria taxes are collected for religious confessions; the Irish Constitution features religious references; and part of the budget in Belgium and Luxembourg is set aside for religious confessions.

As regards the free choice of RE it is observed that in Austria it is still a compulsory subject within the school curriculum. It is also a compulsory subject in schools in Germany and Luxembourg, but students, or their parents 
or guardians if they are under 18 , can request exemption. There are also countries where this education can be freely requested, as is the case of Belgium and the Netherlands. Although it is not obligatory in Ireland, the country's school curriculum is imbued with a religious and moral education.

In general, the content and textbooks of these countries are decided and approved by the different religious confessions and subsequently ratified by the educational administrations. This is the case of Germany, Austria, Belgium, Ireland and Luxembourg.

No alternative subjects to RE are on offer in Austria (although some schools have recently started offering them). However, optional subjects are on offer in Germany, Belgium, the Netherlands, and Luxembourg.

We are in agreement with most of the international declarations and national constitutions when they state that parents have the right and obligation to educate their children. As the ultimate aim of the education process is the integral development of the students, all their skills and potentials should be exercised in order to provide them with an education that can make them independent people with ideals of their own. Obviously, for someone with religious principles the aspect of religion should also be part of their children's education. Another matter is how this should be executed, taking into account the rights of the rest of the students, even if in the case of EU citizens they are in a minority. However, what should really be questioned is whether this education should be carried out in state schools and how it should be carried out. In this regard we feel it is essential to open up academic dialogue towards the religious and spiritual, as is being called for (Iranzo, 2013).

\section{References}

Assemblée nationale. (2004). LOI $n^{\circ}$ 2004-228 du 15 mars 2004 encadrant, en application du principe de laïcité, le port de signes ou de tenues manifestant une appartenance religieuse dans les écoles, collèges et lycées publics. Retrieved from https://www.legifrance.gouv.fr/affichTexte.do?cidTexte=JORFTEXT000000417977 $\&$ dateTexte $=\&$ categorieLien $=\mathrm{id}$

Austria National Council. (1949). Federal Law Gazette 190/1949. Retrieved from $\mathrm{http} / / /$ eur-lex.europa.eu/n-lex/legis_at/ris.bgbla_form_en

Barnes, P., \& Felderhof, M. (2014). Reviewing the religious education review. Journal of Beliefs and Values, 35(1), 108-117. https://doi.org/10.1080/13617672.2014.884909

Borsenberger, M., \& Dickes, P. (2011). Religions au Luxembourg. Quelle évolution entre 1999-2008? Les Cahiers $d u \quad$ CEPS/INSTEAD, 2, 3-35. $\quad$ Retrieved from http://www.statistiques.public.lu/catalogue-publications/cahiers-CEPS/2011/02-religions.pdf

Constitution de la Belgique. (1831). Révisé février 17. 1994. Sur la base de la Constitution originelle de 1831 et ses modifications ultérieures. Retrieved from https:/www.dekamer.be/kvvcr/pdf_sections/publications/ constitution/grondwetFR.pdf

Constitution de la République Française. (1958). Révisé le 4 Octobre 1958. Retrieved from http://www.assemblee-nationale.fr/connaissance/constitution.asp

Constitution du grand-duché de Luxembourg. (1868). Promulguée le 17 octobre 1868, plus tard, subissent plusieurs modifications. Retrieved from http://data.legilux.public.lu/file/eli-etat-leg-recueil-constitution20161020-fr-pdf.pdf

Constitution of Ireland. (2004). Text enrolled on 27 May, 1999, Twenty-seventh Amendment of the Constitution Act. Retrieved from https://www.constitution.ie/Documents/Bhunreacht_na_hEireann_web.pdf

Council of Europe (1952). Protocol to the Convention for the Protection of Human Rights and Fundamental Freedoms. Retrieved from https://rm.coe.int/168006377c

Council of Europe. (1950). European Convention on Human Rights of 4 November 1950. Retrieved from http://www.echr.coe.int/Documents/Convention_ENG.pdf

Département Opinion et Stratégies d'Entreprise. (2010). Le catholicisme en France en 2010. Retrieved from http://www.ifop.com/media/pressdocument/238-1-document_file.pdf

Die österreichische Bundesverfassung. (1920). Gesetz vol 1, womit die Republik Österreich als Bundesstaat eingerichtet wird. Retrieved from http://www.konvent.gv.at/K/DE/PVORL-K/PVORL-K_00037/imfname_ 035687.pdf

Die Verfassung des Deutschen Reichs. (1919). Vol 11 August 1919. Retrieved from https://www.jura.uni-wuerzburg.de/fileadmin/02160100/Elektronische_Texte/Verfassungstexte/Die_Weimar er_Reichsverfassung.pdf 
Éducation nationale. (2009). Loi du 6 février 2009 portant organisation de l'enseignement fondamental. Retrieved from http://legilux.public.lu/eli/etat/leg/loi/2009/02/06/n3/jo

EUR-Lex. (2004). Tratado por el que se establece una Constitución para Europa. Retrieved from http://eur-lex.europa.eu/legal-content/ES/ALL/?uri=OJ\%3AC\%3A2004\%3A310\%3ATOC

European Commission. (2013). Eurypedia-The European Encyclopedia on National Education System. Retrieved from https://webgate.ec.europa.eu/fpfis/mwikis/eurydice/index.php/Ireland:Population: Demographic_Situation,_Languages_and_Religions

European Union. (2000). Charter of fundamental rights of the European Union. Retrieved from $\mathrm{http}: / /$ www.europarl.europa.eu/charter/pdf/text_en.pdf

European Union. (2005). Treaty establishing a constitution for Europe. Retrieved from https://europa.eu/european-union/sites/europaeu/files/docs/body/treaty_establishing_a_constitution_for_eur ope_en.pdf

García, J. L. (1996). Fundamentos de Educación Comparada (3rd ed.). Madrid: Dykinson.

García, J. L. (2006). La enseñanza religiosa escolar en la Unión Europea. Revista Bordón, 58, 615-626.

General Assembly UN. (1981). Declaration on the Elimination of All Forms of Intolerance and of Discrimination Based on Religion or Belief. Retrieved from http://www.un.org/documents/ga/res/36/a36r055.htm

General Assembly UN. (1989). Convention on the Rights of the Child. Retrieved from http://www.ohchr.org/Documents/ProfessionalInterest/crc.pdf

Goodman, A. (2016). Critical Religious Education (CRE) in practice: evaluating the reception of an introductory scheme of work. British Journal of Religious Education, 1-10 https://doi.org/10.1080/01416200.2016.1256265

Guénois, J. M. (2012). Pourquoi le Concordat s'applique en Alsace-Moselle. Retrieved from http://www.haverford.edu/french/dkight/Fr10),5Spr12/WeekFour/ConcordatMoselle2.pdf

Hand, M. (2015). Religious education and religious choice. Journal of Beliefs and Values, 36(1), 31-39. https://doi.org/10.1080/13617672.2015.1013817

Iranzo, A. (2013). La comprensión del fenómeno religioso y sus desafíos a las Ciencias Sociales. Revista de Estudios Sociales, 47, 183-190. https://doi.org/10.7440/res47.2013.16

Llorent-Bedmar, V. (2002). Educación Comparada. Sevilla: Universidad de Sevilla.

Ministère de l'Éducation Nationale. (2013). Charte de la laïcité à l'École. Retrieved from http://cache.media.eduscol.education.fr/file/Actu_2015/70/3/2015_charte_laicite_A4_NB_447703.pdf

Moreno, J. I. (2013). La enseñanza de la religión en la escuela europea. Retrieved from http://www.aceprensa.com/articles/la-asignatura-de-religion-mejora-con-la-lomce

Parlamentarischen Rat. (1949). Grundgesetz für die Bundesrepublik Deutschland. Retrieved from https://www.bundestag.de/grundgesetz

Parliamentary Assembly. (1999). Recommendation 1396. Religion and democracy. Retrieved from $\mathrm{http} / / /$ assembly.coe.int/nw/xml/XRef/Xref-XML2HTML-en.asp?fileid=16672\&lang=en

Petschen, S. (2008). La religión en la Unión Europea. UNISCI Discussion Papers, 16, $49-59$.

Pol, H. (2008). Religious Education in Netherlands. The European Forum for Teachers of Religious Education. Retrieved from http://www.mmiweb.org.uk/eftre/reeurope/netherlands_2008.html

Rodríguez, B. (2004). Acoso ideológico contra la enseñanza de la religion. Alfa y omega, 405, 3-7.

Serbeto, E. (2013). Así se enseña Religión en otros países de Europa. Retrieved from http://enraizados.org/2013/06/19/asi-se-ensena-religion-en-otros-paises-de-europa

Spanish Centre for Educational Research and Documentation. (2001). La ER en la unión europea y la conferencia internacional consultiva sobre la educación escolar en relación con la libertad de religión de convicciones, la tolerancia y la no discriminación. Boletín de temas educativos, 8, 1-12.

UFAL. (2016). Pour l'application graduelle et négociée de la laïcité en Alsace Moselle. Retrieved from http://www.ufal.info/feminisme-et-laicite/pour-1\%E2\%80\%99application-graduelle-et-negociee-de-la-laicite -en-alsace-moselle/6439 
UNESCO. (1966). Convention against Discrimination in Education. Retrieved from http://www.unesco.org/education/pdf/DISCRI_E.PDF

United Nations General Assembly. (1948). Universal Declaration of Human Rights. Retrieved from http://www.un.org/en/udhrbook/pdf/udhr_booklet_en_web.pdf

United Nations General Assembly. (1966). International Covenant on Economic, Social and Cultural Rights. Retrieved from http://www.ohchr.org/Documents/ProfessionalInterest/cescr.pdf

Verfassung des Königreiches der Niederlande. (1983). Geändert durch siehe Änderungsinde. Weiter in der Fassung der Neubekanntmachung. Retrieved from http://www.verfassungen.eu/nl/verf83.htm

\section{Copyrights}

Copyright for this article is retained by the author(s), with first publication rights granted to the journal.

This is an open-access article distributed under the terms and conditions of the Creative Commons Attribution license (http://creativecommons.org/licenses/by/4.0/). 